Lukács-Nagy Gitta ${ }^{1}-$ Fodor Szilvia ${ }^{2}$

${ }^{1}$ Debreceni Egyetem

${ }^{2}$ Debreceni Egyetem, Pszichológiai Intézet

\title{
Hogyan dicsérjek?
}

\section{A dicséretek hatása a feladatválasztásra és az intelligencia formálhatóságára vonatkozó szemléletmódra}

A pozitiv megerôsitések hasznossága, személyiségépitố hatása a nevelés és az oktatás terén is egyre inkább a kutatások érdeklódési körébe kerül. Carol Dweck, az amerikai Stanford Egyetem kutatója

számos tanulmányában kimondja: eddig tévúton jártunk, ha azt hittük, a dicséretnek kizárólag konstruktív hatása lehet. Nemcsak hátráltatnak és motiválatlanná tesznek a nem megfeleló szavak, hanem akár szorongást, görcsös megfelelési vágyat is kialakithatnak, míg a jó dicséret erôsiti a fejlốdóképességünkbe vetett hitet és bátorít a nehezebb feladat elvégzésére.

Vizsgálatunkban 69 ötödikes tanuló mintáján tanulmányoztuk a dicséret hatását a feladatválasztására és a beállitódásra, mely rámutat az erôfeszítésre irányuló dicséret pozitív hatásaira.

A motiváció és a kitartás a képességek mellett fontos alkotóeleme a kitünő teljesítménynek és a sikernek (Duckworth és Seligman, 2005), ezért az oktatásban is fontos feladat ennek erősítése, növelése. A dicséret és a pozitív visszajelzés a megerősítés-alapú behaviorista motivációs elméletek szerint fontos jutalmazási forma, és az adott viselkedés előfordulási gyakoriságát növelö, motiváló hatású. Ennek fényében az intelligenciát, a képességet, az elért eredményeket dicsérni kiemelkedően fontos egy gyermek életében, amely pozitív változásokat eredményezhet előrehaladásában, teljesítményében. A szülők 85\%-a fontosnak tartja azt, hogy megdicsérjék gyermekük képességeit, ha egy feladatban jól teljesít (Mueller és Dweck, 1996). Ez a nézőpont azonban nem minden szempontból eredményes, mivel a dicséret által kiváltott folyamatok sokkal komplexebbek. A dicsérettel az énkép és az önbecsülés formálódik, nem ritka viszont az sem, hogy deformálódik. Ez a hatása már kevéssé ismert, az ezirányú kutatások viszonylag újkeletúek (1. pl. Murphy és Allen, 2007; Ricci, 2013)

\section{Képesség a változásra - a mindset elmélet}

A motivációval kapcsolatban Carol Dweck (2006) a mindset-elméletben foglalja össze a képességek fejleszthetőségébe vetett hit hatását a tanulás és gyakorlás folyamatára. A középpontba a tanulás szeretetét, a hibákból való tanulást helyezte. Alapvetően két különböző gondolkodásmódot ír le, melyek a képességek fejleszthetőségével kapcsolatban a stabilitás vagy a megváltoztathatóság alapgondolataira épülnek. A képességek stabilitását, megváltoztathatatlanságát képviselő személy azt gondolja az intelligenciáról, 
így saját képességeiről is, hogy azok stabilak, már születéstől fogva adottak, a génekben vannak kódolva, így azokat alapvetően nem lehet megváltoztatni. Aki szüleitől, nagyszüleitől azt kapta, hogy ö okos, tehetséges, annak tanulnia sem kell a sikerhez, illetve veszít az igyekezettel, az erőfeszítéssel, mert ha mégis kudarc éri, az egyenlő a tehetségének felülbírálatával, azaz azzal, hogy ő buta. Aki megbukik egy vizsgán, az alapvetően két módon reagál a helyzetre (Dweck és Legett, 1988; Dweck, 2006): az előbb említett nézőpont szerint csalódik önmagában és kétségbe vonja saját képességeit, magába temetkezik és kudarcként tekint a helyzetre - ő a rögzült beállítódással (fixed mindset) rendelkezőek közül való. Azonban létezik egy másik út is, mikor a kudarc fogalma új színezetet kap. A kudarc az, mikor nem igyekszik az egyén eléggé, vagy nem gyakorol, nem próbálkozik, hanem feladja. A fejlődésorientált beállítódás (growth mindset) szerint egy vizsgán megbukni azt jelenti, hogy a tudásban olyan hiányosságok vannak, amiket lehetséges és szükséges is pótolni. Ez nem rögzít egy statikus állapotban, ugyanakkor nem is engedi a személy számára kényelmes kifogások használatát. Az intelligencia mért szintje csupán a fejlődés egy adott pontját jelenti az ilyen típusú emberek számára, ami minden ember egyéni felelőssége, és lehetősége annak megváltoztatására.

\section{A dicséreti típusok}

A tanulók dicsérete egy általános visszajelzési és motivációs módszer, mellyel gyakran jutalmazzák a fiatalabb tanulókat. Az idősebbeknél ez már némileg átalakul, és a viszszajelzés során inkább a hibákra hívják fel a figyelmet (Balogh, 2006), ezzel segítve a helyes megoldás elérését. Mivel a rossz viselkedést és a gyengébb teljesítményt könnyebb észrevenni, így maguk a tanulók is arra fognak fókuszálni, hogy nehogy hibát kövessenek el (Balogh, 2006). Ehhez hozzáadódik, hogy az iskolák, és gyakran a szülők is, igen teljesítményközpontúak, az iskolának produkálnia kell a megfelelö és jól látható eredményeket, növelnie a felvett tanulók számát és az egyéb látható teljesítményeket (Pajor, 2013), így csupán kevés eszköz áll az iskolák rendelkezésére, hogy a teljesítménykényszer és a gyerekekre nehezedő teher mögött megmutassa a tanulás igazi örömét is.

A fejlődésorientált beállítódás szerint a dicséret legfontosabb funkciója az erőfeszítések jutalmazása, így a tanuló nem a végeredményre koncentrál, hanem magára a folyamatra. Ez hasonlatos az intrinzik motivációhoz, mikor magáért a tevékenységért végzi valaki a munkáját (Atkinson és mtsai, 2005; Pajor, 2013), a tevékenység célja pedig a fejlődés és a tanulás. A képesség, az intelligencia dicsérete ezzel szemben nem az igyekezetet, hanem a már meglévő képességeket tartja szem előtt, így voltaképp az eredmény leértékelődik általa olyan módon, hogy az egyén egy bizonyítási körbe kerül be, ahol kedvező színben akarja feltüntetni adottságait. A célok középpontjába így a fejlődés helyett egyre inkább a látható teljesítmény kerül (Dweck és Leggett, 1988).

Mueller és Dweck (1998) hat kísérletben bizonyította, hogy az igyekezet, a szorgalom és az erőfeszítés dicsérete több pozitív következménnyel jár, mint ha az intelligenciát, képességet dicsérik. 10-11 éves gyerekek vizsgálata során a feltevésük az volt, hogy azok a gyerekek, akiknek az intelligenciáját dicsérik, inkább a teljesítménycélokkal foglalkoznak, míg akiknek az igyekezetét dicsérik, azok a tanulási célokat helyezik elötérbe. Ez megnyilvánulhat abban is, hogy a szorgalmukért dicsért gyerekeknek nagyobb a kitartásuk, a teljesítményük, jobban élvezik a feladatot még annak elrontása, egy kudarcélmény után is. A tanulmány rámutat, hogy a kudarctól félő tanulók szorongásaikból kiindulva gyakran hasonlítják eredményeiket a társaikhoz, illetve megfogalmazza, hogy hogyan lehet a dicséreten keresztül a sikert a legjobban elösegíteni, a teljesítményt növelni, ezzel segítséget nyújt a pozitívabb önértékelés kialakításához. 


\section{Az intelligencia és motiváció kapcsolata a mindset elmélettel}

A dicséreti típusok problémája ott rejtőzik, hogy a köztudatban többnyire egy determinált, statikus rendszerként jelenik meg az intelligencia fogalma, így természetes, hogy az arra adott visszajelzést a teljesítményre és az eredményességre is vonatkoztatjuk. Azonban nem szükségszerü, hogy így gondoljunk rá (Vajda, 2002). A velünk született tényezők valóban meghatározzák, hogy egy ember képességei milyen szintre fejleszthetőek fel, az azonban igen komplex interakciók eredménye, hogy valaki maximálisan tudjon egy adott feladathelyzetben teljesíteni. Egy klasszikus kísérlet alátámasztja azt a feltételezést, hogy a motivációnak jelentős szerepe van nemcsak az intellektuális képességek kialakulásában, de a tudásanyag egy aktuális helyzetben való visszahívásában is: alacsony társadalmi státuszú családokból jött 5-7 éves gyerekek intelligenciáját mérve azt tapasztalták, hogy szignifikánsan jobb teljesítményt értek el azok a gyerekek, akiket M\&M's csokoládédrazsékkal jutalmaztak a helyes megoldásokért (Edlund, 1972, idézi Tough, 2013). A motiváció intelligenciahányadosra gyakorolt hatásáról végeztek kutatást Angela Duckworth és munkatársai (2011) is, akik rámutatnak, hogy az intelligenciatesztek gyakran nem a maximális teljesítőképességet mérik, illetve hogy azok eredményét sok egyéb tényező, például a tesztmotiváció is befolyásolja.

Egy másik vizsgálat során több mint 300 13 éves tanulót kérdeztek meg azzal kapcsolatban, hogy mit gondolnak az intelligenciáról, majd követték a válaszadók tanulmányait két éven keresztül (James, 2008). A saját vizsgálatunkban is felhasznált mondatokat értékeltették a gyerekekkel, úgymint „Nagymértékben képes vagy változtatni az értelmi képességeiden” vagy „Az intelligenciád egy olyan veled kapcsolatos dolog, amin nem sokat tudsz változtatni”. Az eredmény azt mutatta, hogy azok a tanulók, akik megváltoztathatónak tartják az intelligenciát, jobban teljesítettek két év múlva matematikából, mivel ők kudarc esetén nem voltak
A dicséreti típusok problémája ott rejtózik, hogy a köztudatban többnyire egy determinált, statikus rendszerként jelenik meg az intelligencia fogalma, így természetes, hogy az arra adott visszajelzést a teljesítményre és az eredményességre is vonatkoztatjuk. Azonban nem szükségszerü, hogy így gondoljunk rá (Vajda, 2002). A velünk született tényezók valóban meghatározzák, hogy egy ember képességei milyen szintre fejleszthetóek fel, az azonban igen komplex interakciók eredménye, hogy valaki maximálisan tudjon egy adott feladathelyzetben teljesiteni. Egy klasszikus kisérlet alátámasztja azt a feltételezést, hogy a motivációnak jelentôs szerepe van nemcsak az intellektuális képességek. kialakulásában, de a tudásanyag egy aktuális helyzetben való visszahívásában is: alacsony társadalmi státuszú családokból jött 5-7 éves gyerekek

intelligenciáját mérve azt tapasztalták, hogy szignifikánsan jobb teljesítményt értek el azok a gyerekek, akiket MEM's csokoládédrazsékkal jutalmaz-

tak a helyes megoldásokért

(Edlund, 1972, idézi Tough, 2013). 
tanácstalanok, nem adták fel, hanem megkettőzött energiával láttak neki a következő feladatnak.

A pedagógusoknak igen fontos szerepe lehet abban, hogy ezeket a tanulságokat bevonják módszereikbe és a tanulókat időről-időre emlékeztessék arra, hogy magukban hordozzák azt a képességet, hogy okosabbak legyenek, mivel az agy plasztikus és elég rugalmas ahhoz, hogy fejlődni tudjon és új információkat fogadjon be (Doidge, 2007; Ricci, 2013).

\section{A vizsgálat bemutatása}

A fentiek alapján szerettük volna empirikusan is alátámasztani, hogy a fejlődésorientált dicséret hatással van a tanulók motivációjára, így elsődleges célunk az volt, hogy a különböző beállítódások (mindset) vonatkozásában tanulmányozzuk a visszajelzések hatását a teljesítményre és a későbbi feladatválasztásra.

A vizsgálatunkban összesen 69 általános iskolás, 10-11 éves tanuló vett részt két Hajdú-Bihar megyei általános iskolából. Mindkét iskolába nagyrészt átlagos vagy jó körülmények közül jött tanulók járnak, ezen kívül pedig az iskolák általános jellemzőkkel bírnak. A korcsoport választását több tényező indokolta. Egyrészt ez a korosztály többnyire még igen fontosnak tartja a pedagógustól vagy más felnőttektől kapott dicséretet, visszajelzéseket, míg az idősebbek már inkább a kortársaikhoz mérik magukat, tőlük várnak megerősítést (Balogh, 2006). Másrészt ez a korcsoport már érti a „képesség” fogalmát, tudják helyesen használni az ehhez kapcsolódó fogalmakat, ami fontos szempont volt a kérdőív megértéséhez (Dweck, 2002). Harmadsorban pedig a vizsgálatsorozatunk ötletét adó kísérletet is ebben a korosztályban végezték (Mueller és Dweck, 1998), így az eredmények összehasonlíthatósága érdekében érdemes volt ugyanolyan életkorúakkal végezni a kutatást.

A vizsgálat során tesztekkel és kérdőívekkel mértük a gyerekek különböző jellemzőit (intelligencia és mindset), majd megfigyeltük a viselkedésüket egy feladathelyzetben, mely során három csoportba sorolva őket különböző dicsérettípusokat - erőfeszítésre vonatkozó, képességekre vonatkozó és semleges visszajelzéseket - nyújtottunk nekik. Emellett a féléves tanulmányi átlagukat is feljegyeztük, mely az iskolai eredményességről nyújtott információt. Az intelligencia, a mindset és a dicséret hatására vonatkozóan a következő hipotéziseket fogalmaztuk meg:

1. Az intelligencia nincs kapcsolatban a fejlödésorientált beállítódással.

2. Az intelligencia és a tanulmányi átlag összefüggésben áll egymással.

3. A dicséret típusa meghatározza a feladatválasztást, azaz hogy a későbbiekben milyen nehézségü feladatot választanak a gyerekek. A fejlődésorientált beállítódás szerint dicsért tanulók nehezebb feladatot, míg a képesség szerint dicsért tanulók könnyebbet fognak választani, míg a kontroll csoport a közepes nehézségű feladatot részesíti elönyben.

4. A elsődleges, a dicséretek előtt mért beállítódás (mindset) nem mutat összefüggést a feladatválasztással.

5. A vizsgálat előtt és után mért beállítódás változást mutat: a képességet dicsérő csoport esetében a rögzült irányba történik változás, míg a kontroll csoportnál nem változik. 


\section{Módszerek}

A gyerekek általános gondolkodóképességének vizsgálatára a Standard Raven Progreszszív Mátrixok intelligenciatesztet használtuk. Ez egy világszerte használt, nem verbális képességteszt, mely csoportosan is felvehető. A feladatok megoldása során meg kell találni a bemutatott ábrák szabályszerü mintázatait komplex logikai műveletek útján. A standard változat a hét és tizennégy éves közti gyerekek intellektuális képességeit jól méri.

A beállítódás (mindset) vizsgálatára a Carol Dweck (2006) által leírt mindset-elmélet alapján készült rövid, tanulók számára készített kérdőívet használtuk, mely hat állítást tartalmaz az intelligenciával kapcsolatos attitüdökre vonatkozóan. A gyerekeknek egy hatfokú skálán kell bejelölniük, hogy mennyire értenek egyet az állításokkal, így összesen 36 pontot lehet elérni. Ez jelenti a kontinuum egyik végpontját, az illető ebben az esetben szélsőségesen rögzült beállítódásra jellemző nézeteket vall, míg a minimum pontszám a hat volt, ebben az esetben az egyén fejlődésorientált látásmóddal rendelkezik. Tehát minél alacsonyabb pontja van valakinek, annál inkább jellemező rá a fejlődésorientált gondolkodásmód.

A Raven-teszt és a mindset-kérdöív csoportos felvétele után néhány nappal történt a gyerekek egyenkénti vizsgálata. Fontos volt, hogy a gyerekek lehetőleg kevés szorongással érkezzenek és az iskolai teljesítményhelyzettől megkülönböztethető feladatokat végezzenek. Egy-egy ilyen vizsgálati helyzet kb. 15 percig tartott, a feladatok pedig a Hawik és MAWI intelligenciatesztekből ismert mozaik teszt kirakós kockáival voltak végezhetőek. Ezeket a legtöbb gyerek élvezettel rakosgatja, és kissé kiszakítja őket az iskolai papír-ceruza alapú feladatok köréből. A teljes vizsgálat a szülők aktív beleegyezésével történt.

A vizsgálat menete a következő volt:

Előzetesen minden gyereket véletlenszerűen besoroltunk a három dicséret-típusra kialakított csoport egyikébe. Az egyik csoportot az erőfeszítés alapján, az igyekezet buzdításával dicsértük, pl. „Látom, hogy nagyon igyekszel”, „Jól dolgoztál”, vagy „Ha még gyakorolsz, nagyon jó leszel benne..”, így erősítve a fejlődésorientált beállítódást. A másik csoportot a képességei alapján, a rögzült beállítódás mintájára dicsértünk, pl. „Te nagyon intelligens vagy”, vagy „Te tényleg igazán jó képességü vagy”. Ezen túl volt egy harmadik, kontrollcsoport is, akik semleges visszajelzéseket kaptak (pl. „Rendben”.)

A vizsgálat elején a gyerekeknek három ábrát kellett kirakniuk, elöször négy kockából a Hawik 3-as, majd 4-es ábráját, majd a már kilenc kockából álló kicsit nehezebbet, az 5-ös ábrát. Ezek a feladatok lényegében minden gyereknek sikerültek (esetleg kis segítséget kaphattak), ami igen fontos volt, hiszen a helyes feladatmegoldás és az ezt követö visszajelzés volt a vizsgálat fő fókuszában. Az egyes feladatmegoldások után a gyerekek a véletlenszerüen kialakított csoportoknak megfelelő dicséretet kapták.

Ekkor következett a feladatválasztás: a gyerekek három különböző nehézségű feladat közül választhattak, mely során ugyanazt a mintát (17-es ábra a MAWI-ból) kellett négy, kilenc vagy tizenhat kockából kirakni, azaz egy könnyü, egy közepes vagy egy nehéz feladat közül választhattak. Olyan ábrát kerestünk, mely kirakható mind a három módon, így tisztán a feladat nehézségét variáltuk, és a gyerekek választása sem tulajdonítható másnak, pl. hogy jobban tetszik nekik valamelyik ábra. A kérdés így hangzott: „Most pedig te döntheted el, hogy milyen nehézségü feladatot szeretnél megcsinálni. Van négy, kilenc vagy tizenhat kockából álló. Melyiket választod?" Feljegyeztük a válaszukat, majd miután elkészültek, megdicsértük őket a megfelelő módon. Végül felvettünk velük újra a néhány nappal korábban már felvett mindset-kérdőívet, és megköszöntük a részvételt. 


\section{Eredmények}

1. Az intelligenciateszt eredményének nincs szignifikáns kapcsolata a mindset-kérdőívvel.

Az intelligenciateszt eredménye normál eloszlást mutatott, a legtöbb gyerek 15-20 hibával teljesítette a tesztet. A mindset-kérdőívben mutatott eredmények szerint az átlag pontszám 17,2 volt, ami a 6-36-os pontszámterjedelmet tekintve arra mutat, hogy inkább a fejlődésorientált gondolkodásmód felé tolódik a gyerekeknek a képességek megváltoztathatóságára vonatkozó elképzelése. A hipotézisünk fő kérdésének vizsgálatára korrelációs vizsgálatot alkalmaztunk. A Spearman-féle korrelációs eljárás eredménye szerint nincs kapcsolat a Raven Progresszív Mátrixok intelligenciateszt és a mindset-kérdöív eredménye között ( $\mathrm{rho}=-0,14, \mathrm{p}=0,25)$. Ez a korrelációs eredmény alátámasztja az előzetes elvárásunkat, így azt igazoltnak tekinthetjük: nem az értelmi képességeken alapul az, hogy kinek mi a véleménye az intelligencia fejleszthetőségéröl, és hogy rögzült vagy fejlődésorientált-e a beállítódása. E szerint egy magas intelligenciájú egyén is képviselöje lehet a rögzült beállítódásnak, valamint egy alacsonyabb képességü tanuló is rendelkezhet fejlődésorientált beállítódással (lehetséges, hogy saját képességeihez mérten teljesít jól).

2. Az intelligenciateszt és a tanulmányi átlag összefüggése kimutatható.

Az intelligenciateszt eredménye és a tanulmányi átlag között szignifikáns, de nem túl erős kapcsolat mutatható ki, mivel a Spearman-féle korrelációs együttható értéke 0,36 $(\mathrm{p}=0,002)$. Ezzel a hipotézist igazoltnak tekintjük.

3. A dicséret típusa meghatározza a feladatválasztást, azaz hogy milyen nehézségü feladatot választanak a gyerekek. A fejlődésorientált beállítódás szerint dicsért tanulók nehezebb feladatot, míg a képesség szerint dicsért csoport könnyebbet választanak, a kontroll csoport pedig a közepes típusú feladatot részesíti előnyben.

A 69 tanulóból 22-en választották a könnyü feladatot, ahol csak négy kockából kellett kirakni az ábrát, 31-en a közepeset, ahol ugyanazt már kilencböl kellett, és 16-an a nehezet, ahol 16 kocka állt a rendelkezésükre. Az 1. számú táblázat részletesen mutatja a három feladattípus választásának arányait. A könnyü feladatot a képességre fókuszálóan dicsért csoport választotta leginkább, majd a kontroll csoport, és végül az erőfeszítésért dicsért csoport. Ez megfelel elözetes elvárásainknak. A közepes feladatot legtöbben a kontroll csoportból választották, a fejlődésorientált csoport és a rögzült beállítódás szerint dicsért csoport között azonban alig van különbség a közepes feladat tekintetében (mindössze 1\%). Ezt tehát leginkább azok választották, akik nem húznak egyik irányba se, megmaradnak a középútnál. Végül a nehéz feladatot legtöbben az erőfeszítés szerint dicsért gyerekek csoportjából választották, 10\%-os az eltérés a képesség szerint dicsért csoport választásától. Ezt a nehézségü feladatot a kontrollcsoport tagjai választották a legkevesebben, akik semmilyen dicséretet nem kaptak. A statisztikai elemzés eredménye azonban a jól látható különbségek ellenére nem mutatott szignifikáns különbségeket a három csoportra nézve (Pearson-féle Khi négyzet próbával $\mathrm{p}=0,65$ ), ami az alacsony elemszám miatt is várható volt. 


\begin{tabular}{|c|c|c|c|}
\hline $\begin{array}{l}\text { Feladat nehézsége } \\
\text { Dicséret típusa }\end{array}$ & Könnyü & Közepes & Nehéz \\
\hline $\begin{array}{l}\text { Fejlődésorientált } \\
\text { (eröfeszítésre vonatkozó) N=22 }\end{array}$ & $27,3 \%$ & $40,9 \%$ & $31,8 \%$ \\
\hline Rögzült (képességekre vonatkozó) N=23 & $39,1 \%$ & $39,1 \%$ & $21,7 \%$ \\
\hline Nincs (kontroll) $\mathrm{N}=24$ & $29,2 \%$ & $54,2 \%$ & $16,7 \%$ \\
\hline
\end{tabular}

A hipotézis alapos körbejárása érdekében egyes nehézségszintek elhagyásával, illetve összevonásával is megtörtént az elemzés. A 2. számú táblázaton látszik, mi történik, ha kivesszük a közepes nehézségü feladatot, és csak a könnyü és nehéz feladatok választását hasonlítjuk össze. Ez alapján látszik, hogy lényegesen többen $(53,8 \%)$ választották a 16 kockából álló ábra kirakását az erőfeszítést dicsért csoportból, mint a másik kettőből. Az intelligenciájukért dicsért gyerekek 64,3\%-a választotta a könnyebb feladatot, és csupán $35,7 \%$ a nehezebbet. Ezeket az adatokat szintén elemeztük Khi-négyzet próbával, azonban ez sem mutatta a táblázatok alapján várt eredményeket, sem a közepes nehézségü feladat kihagyása, sem pedig a közepes feladat összevonása a nehézzel vagy a könnyüvel nem eredményezett szignifikáns különbséget a csoportok között.

2. táblázat. A könnyü és a nehéz feladat választásának arányai

\begin{tabular}{lccc}
\hline $\begin{array}{l}\text { Feladat nehézsége } \\
\text { Dicséret típusa }\end{array}$ & Könnyü & Közepes & Nehéz \\
\hline $\begin{array}{l}\text { Fejlödésorientált } \\
\text { (erőfeszítésre vonatkozó) N=22 }\end{array}$ & $46,2 \%$ & $53,8 \%$ & $31,8 \%$ \\
\hline Rögzült (képességekre vonatkozó) N=23 & $64,3 \%$ & $35,7 \%$ & $21,7 \%$ \\
\hline Nincs (kontroll) N=24 & $63,6 \%$ & $36,4 \%$ & $16,7 \%$ \\
\hline
\end{tabular}

Érdekes eredmény, hogy a kontrollcsoport és a képességet dicsért csoport hasonló arányban választja a könnyü feladatot, ami azzal is magyarázható, hogy a szülői és tanári dicséretek módja alapvetően hasonló, a rögzült gondolkodásmódot erősítő és képességekre irányuló, emiatt pedig a gyerekekben is erős a megfelelés, a képesség- és teljesítményorientáltság köré szerveződő alapbeállítottság. A dinamika azonban jól látszik, miszerint az erőfeszítés hangsúlyozása megváltoztathatja a beállítódást, és fejlődésközpontúbbá teheti a gyermek gondolkodásmódját.

4. A mindset-kérdőív eredménye nem mutat szignifikáns összefüggést a feladatválasztással.

A mindset-kérdőív eredményének átlaga 17,2 volt, az ennél kevesebb pontot elérőket soroltuk a fejlődésorientált $(\mathrm{N}=34)$, míg az ennél több pontot elért tanulókat a rögzült beállítódású csoportba $(\mathrm{N}=35)$. A különböző nehézségü feladatokat választó tanulók mindset-eredményeit áttekintve azt láttuk, hogy a feladatválasztás alapvetően egyenletesnek tünik, a könnyü és a nehéz feladatot választók mindset pontszáma 17,5, míg a közepes feladatot választóké 16,3. Az egyszempontos varianciaanalízis szerint nincs szignifikáns kapcsolat $(\mathrm{p}=0,7)$ a mindset-kérdőív és aközött, hogy milyen nehézségü 
feladatot választanak a gyerekek. Ez igazolta a feltevésünket, miszerint a feladatválasztásra elsődlegesen nem a tanulók eredeti beállítódása lesz hatással, hanem a dicséret típusa.

5. A vizsgálat előtt és után mért mindset különbséget mutat: a fejlődésorientált, erőfeszítésre vonatkozó dicséretet kapók esteében fejlődésorientált, a rögzült, képességekre vonatkozó dicséret esetében rögzült irányba, míg a kontrollcsoport esteében nem várunk változást.

Az első mindset-kérdőív eredménye szerint a 69 vizsgálatban szereplő tanulóból 34 fejlődésorientált beállítódást mutatott (átlag, azaz 17,2 alatti pontja volt), a kísérlet végén viszont már 45 személynél látható ilyen beállítódás, míg a rögzült beállítódás képviselőinek száma ennek megfelelően csökkent. A pontszámok alakulását a 3. táblázat mutatja. A három csoport mindset pontszámának változásait csoportonként páros t-próbával vizsgáltuk. Eszerint a képességért dicsért csoport kísérlet elött és után mért mindset eredményei között nem történt jelentős változás $(\mathrm{p}=0,31)$, míg szignifikáns csökkenés (azaz a fejlődésorientált gondolkodásmód irányába történő változás) látható az erőfeszítésért dicsért csoportban $(\mathrm{p}=0,027$, azaz $\mathrm{p}<0,05)$ és a kontrollcsoportban (dicséretet nem kapók) is $(\mathrm{p}=0,026)$. Ez az eredmény arra hívja fel a figyelmet, hogy egy viszonylag rövid beavatkozás, azaz az erőfeszítésre irányuló dicséret adása a tanulók gondolkodásmódját rövid távon meg tudja változtatni. A táblázat mutatja, hogy bár mindkét csoport (erőfeszítésért dicsért és kontrollcsoport) esetében szignifikáns a csökkenés, az erőfeszítésért dicséretet kapó csoport mindset-pontszámának átlagos csökkenése 4,2 pont, míg a kontrollcsoporté csupán 1,7, tehát mindkét helyzetben fejlődésorientáltabbá váltak a gyerekek, csak különböző mértékben. De miért történt ez meg a semleges módon dicsért csoportban? Meglátásunk szerint ennek magyarázata abban kereshető, hogy lényegesen másabb típusú feladatot kellett megoldaniuk a gyerekeknek, mint amit az iskolai órákon megszoktak, így a kreativitást is igénylő játékos feladvány a fejlődésorientáció felé húzhatta a gyerekeket. Ugyanilyen hatással lehetett az is, hogy a kezükben volt a választás lehetősége, ez pedig asszociálódott a gondolkodásukban azzal, hogy kitartással és munkával kiterjeszthetik képességeik mértékét.

Összességében tehát a hipotézisünket részben igazoltnak tekintjük, míg a képességért dicsért csoporttal kapcsolatos elvárásunkat elvetettük.

3. táblázat. A három különbözöképpen dicsért csoport mindeset-pontszáma a vizsgálat elött és után

\begin{tabular}{lccc}
\hline Dicséret típusa & $\begin{array}{c}\text { Erőfeszíté- } \\
\text { sért dicsért } \\
\text { csoport }\end{array}$ & $\begin{array}{c}\text { Képessé- } \\
\text { gért dicsért } \\
\text { csoport }\end{array}$ & $\begin{array}{c}\text { Kontroll csoport } \\
\text { (semleges, } \\
\text { nincs dicséret) }\end{array}$ \\
\hline $\begin{array}{l}\text { Mindset 1 } \\
\text { (elözetes mindset eredmények átlaga) }\end{array}$ & $\mathbf{1 9 , 7}$ & 16,9 & $\mathbf{1 5 , 5}$ \\
\hline $\begin{array}{l}\text { Mindset 2 } \\
\text { (utólagos mindset eredmények átlaga) }\end{array}$ & $\mathbf{1 5 , 5}$ & 15,8 & $\mathbf{1 3 , 8}$ \\
\hline
\end{tabular}

\section{Szubjektív észrevételek}

A hipotézisekben nem szerepeltek ugyan, de a vizsgálat során további érdekes eredményeket láttunk. A 23 képességüket dicsért egyénből 10 fejlödésorientált gondolkodásmódú volt, és a rögzült jellegü dicséret ellenére is azok maradt utána, csak kisebb változást mutattak, azaz 1,4 ponttal nőtt az eredményük a rögzült irányba (12,8 volt az átlag, majd a kísérlet után nekik 14,2-re nőtt). Ez arra enged következtetni, hogy 
a fejlődésorientált beállítódás viszonylag stabilnak mondható jellemző, ami ha már kialakult, csak szélsőséges esetben változik. Az egyik tanulóról például elmondható, hogy erősen fejlődésorientált (első mindset-pontszáma kilenc) volt, és bár a képességek hangsúlyozása szerint kapott dicséretet, ez nem változtatott a hozzáállásán. Sőt a nehéz feladatot választotta és még a mindset kérdőív eredménye is csökkent. A 10 tanuló feléről mondható el, hogy nehéz feladatot választott a fejlődésorientált nézeteinek megfelelően, fele pedig a közepest választotta.

A kitartás, szorgalom épp annyira hozzájárul a jó teljesítmény eléréséhez, mint a megfelelő értelmi képességek megléte (Duckworth és Seligman, 2005), és ezek mindegyikét lehetséges megfelelő erőfeszítéssel fejleszteni, ezt azonban sajnos sok tanuló nem hiszi el magáról. A kísérletben részt vett egy 11 éves lány is, aki láthatóan nem bízott saját képességeiben. Ezzel ítéli magát kudarcra minden ember, aki önértékelési problémákkal küszködik, vagy rögzült beállítódásának köszönhetően a nehézségek sorozata formálta ilyenné. Csak a vizsgálat után ismertük meg a gyermek tanulmányi eredményeit, ami alapján kiderült, hogy ez a tanuló elég alacsony tanulmányi átlaggal rendelkezik. A kísérlet során ugyanakkor azt tapasztaltuk, hogy a fejlödésorientált dicséretek hatására nagyon felbátorodott, és kis biztatással gyorsan és ügyesen ki tudta rakni a mintákat, ábrákat. Ebből azt a következtetést vonhatjuk le, hogy amennyiben a pedagógusok figyelmet fordítanak ennek a tanulónak a visszajelzés iránti szükségleteire, sokkal jobb eredményeket is képes lesz elérni. Bár kevés az ennyire látványos változás, ennek ellenére figyelemfelkeltőek ezek az egyéni tapasztalatok.

\section{Összegzés}

Carol Dweck (2006) kutatásai szerint a képességek fejleszthetőségével kapcsolatos gondolkodásmódunk jelentős szerepet játszik a teljesítmény motivációs alapjainak megteremtésében. A fixed, azaz rögzült, stabil látásmódú személy alapvetően kudarckerülő, sikereit és hibáit belső és megváltoztathatatlan tulajdonságnak tekinti, így az adott területre vonatkozó teljesítményhelyzetben kevésbé kitartó, az erőfeszítést a kevésbé jó képességűek számára szükséges feladatnak tartja. Ezzel szemben a growth, fejlödésorientált gondolkodásmód a képességek megváltoztathatósága miatt a siker és a kudarc mögött is inkább a befektetett munkát vagy annak hiányát látja, emiatt nagyobb erőfeszítés tesz a célok elérése érdekében és fejlődni szeretne. A környezet, a pedagógusok és a szülök akár jóhiszemüen, a gyermek „okosságát” túlhangsúlyozva akaratlanul is befolyásolják gyermekeiket, a címkézés miatt gyakran sokszor pont a rögzült gondolkodásmód irányába (Ricci, 2013).

A tanulmányban a dicséret feladatválasztásra és mindset-re gyakorolt hatását vizsgáltuk. A bemutatott kísérletet Mueller és Dweck (1996) tanulmánya alapján állítottuk össze. Az eredmények alapján legfontosabb megállapításaink, hogy bár nem szignifikánsan, de a dinamika szintjén látszik a különböző dicsérettípusok (fejlődésorientált vagy rögzült beállítódást előhívó) befolyása a feladatválasztásra. A tanulók mindset-kérdőív által mért beállítódására ugyanakkor szignifikánsan hatott a dicséret: az erőfeszítései alapján dicsért tanulók gondolkodásmódja elmozdult a fejlődésorientált irányba. A mintanagyságunk a kísérletes elrendezés és az egyéni vizsgálati helyzet miatt igen kicsi, ez eredményezheti, hogy bár százalékos arányokban nézve viszonylag nagy különbségeket látunk, a szignifikanciaszint elérése nem minden hipotézis esetén történt meg. Annak érdekében, hogy ne csak tendenciaszerüen legyen látható a dicséret és a feladatválasztás közti kapcsolat, érdemes nagyobb mintán megismételni a vizsgálatot, valamint hosszabb távú intervenciókat is tanulmányozni, mint például a mentor személy alkalmazása, aki a gyerekekkel való kapcsolatával is változtat a látásmódon, ahogy az Aronson, Good és Inzlicht (2003, idézi Tough, 2013) vizsgálatában is müködött. A fejlődésorientált 
beállítódás, illetve az ezt bátorító visszajelzések összességében segítséget nyújtanak abban, hogy a tanulók, vagy akár a felnőttek teljesítménye növekedjen, ezáltal pedig sikeresebb, eredményesebb, a képességeiket jól kihasználó életet élhessenek. Mindezeket figyelembe véve egyértelmüen látható a dicséreti módszerek vizsgálatának gyakorlati haszna és a további kutatások szükségessége.

\section{Irodalom}

Balogh L. (2006). Pedagógiai pszichológia az iskolai gyakorlatban. Budapest: Urbis Könyvkiadó. 19-29.

Doidge, N. (2011). A változó agy. Elképesztő történetek az agykutatás élvonalából. Budapest: Park Könyvkiadó.

Duckworth, A. L. \& Seligman, M. E. P. (2005). Self-Discipline Outdoes IQ in Predicting Academic Performance of Adolescents. Psychological Science, 16(12), 939-944. DOI: 10.1111/j.14679280.2005.01641.x

Duckworth, A. L., Quinn, P. D., Lynam, D. R., Loeber, R. \& Stouthamer-Loeber, M. (2011). Role of test motivation in intelligence testing. PNAS, 108(19), 7716-7720. DOI: 10.1073/pnas.1018601108

Dweck, C. S. (2002). The Development of Ability Conseptions. In Wigfield, A. \& Eccles, J. S. (szerk.), Development of Achievement Motivation. Academic Press. Letöltve: https://books.google.hu/ books?id=Cv229DRgJ70C\&pg=PA60\&lpg=PA60\&d$\mathrm{q}=$ stipek $+1985 \&$ source $=$ b1\& ots $=\mathrm{G} 4 \mathrm{TqQTCb}-$ $\mathrm{Hg} \& \mathrm{sig}=\mathrm{tErTVDw} g \mathrm{Pc} 8 \mathrm{~s} 6 \mathrm{TpKx}$ moYtNO2PU\&hl=hu\&sa $=$ X\&ei $=$ cnoNVcGKEcrWPLzBgOAI$\&$ ved $=0$ CB8Q6AEwAA\#v=onepage $\& \mathrm{q}=$ stipek $\% 20$ $1985 \& \mathrm{f}=$ false

Dweck, C. S. (2006). Mindset. The new psychology of success. New York: Random House.

Dweck, C. S. \& Leggett, E. L. (1988). A social-cognitive approach to motivation and personality. Psychological Review, 95(2), 256-273. DOI: 10.1037//0033295x.95.2.256

Edlund, C. V. (1972). The Effect ont he Behavior of Children, as Reflected int he IQ Scores, When Reinforced After Each Correct Responce. Journal of Applied Behavior Analysis, 5(3), 317-319. DOI: 10.1901/jaba.1972.5-317

James, O. (2008). Genes don't determine your child's ability. The Guardian. http://www.guardian.co.uk/lifeandstyle/2008/dec/27/family-medicalresearch

Mueller, C. M., Dweck, C. S. (1996). Implicit theories of intelligence: Relation of parental beliefs to children's expectations. Washington, DC.: Poster session presented at Head Start's Third National Conference.

Mueller, C. M., Dweck, C. S. (1998). Praise for Intelligence Can Undermine Children's Motivation and Performance. Journal of Personality and Social Psychology, 75(1), 33-52. DOI: 10.1037//00223514.75.1.33

Murphy, A. P., Allen, J. (2007). Why Praise Can Be Bad for Kids. Abc News. Letöltve: http://abcnews. go.com/GMA/AmericanFamily/story?id=2877896\&page $=1$

Pajor G. (2013). Serdülök teljesitménymotivációja a célorientációs elmélet tükrében. [PhD disszertáció] Eötvös Loránd Tudományegyetem, Budapest. Letöltve: http://pszichologia.phd.elte.hu/vedesek/PAJOR GABRIELLA disszertacio.pdf

Ricci M. C. (2013). Mindsets in the classroom: Building a Culture of Success and Student Achievement in Schools. Waco: Prufrock Press Inc.

Tough, P. (2013). Segitsük kibontakozni gyerekeinket! Budapest: HVG Kiadó Zrt.

Vajda Zs. (2002). Az intelligencia természete. Magyar Pszichológiai Szemle, 57(1), 85-109. DOI: 10.1556/ mpszle.57.2002.1.5

\footnotetext{
Absztrakt

A pozitív megerősítések hasznossága, személyiségépítő hatása a nevelés és az oktatás terén is egyre inkább a kutatások érdeklődési körébe kerül. Carol Dweck, az amerikai Stanford Egyetem kutatója számos tanulmányában kimondja: eddig tévúton jártunk, ha azt hittük, a dicséretnek kizárólag konstruktív hatása lehet. Nemcsak hátráltatnak és motiválatlanná tesznek a nem megfelelő szavak, hanem akár szorongást, görcsös megfelelési vágyat is kialakíthatnak, míg a jó dicséret erösíti a fejlődőképességünkbe vetett hitet és bátorít a nehezebb feladat elvégzésére. Vizsgálatunkban 69 ötödikes tanuló mintáján tanulmányoztuk a dicséret hatását a feladatválasztására és a beállítódásra, mely rámutat az erőfeszítésre irányuló dicséret pozitív hatásaira.
} 